\title{
STRATEGI KLASTER INDUSTRI MENGHADAPI PASAR GLOBAL
}

\author{
Irsad Andriyanto \\ Nurjanah \\ STAIN Kudus
}

\begin{abstract}
ASEAN Economic Community (AEC) 2015 can bring both positive and negative impact on MSMEs. To deal with any negative impacts, SMEs need for strategies to exist and continue growing. One such strategy is the cluster approach. This approach is done by grouping the core industries that are interconnected, both supporting industries (supporting industries), industries related (related industries), supporting services, economic infrastructure, research, training, education, information infrastructure, technology infrastructure, natural resources, and any related institutions. Cluster is also a way to set some economic development activities. Based on the result, Strategies to Increase Industry Competitiveness in Facing ASEAN Economic Community (AEC) is done by: 1. The use of core competencies in seeking to improve the competitiveness clusters. And 2. Creating their competitive advantage cluster based on RBV (Resources Based Value) approach.
\end{abstract}

Key words: competitiveness, strategy, cluster industry

\section{A. Pendahuluan}

Krisis ekonomi yang terjadi pada bulan juli tahun 1997 hin gga kin i te rus berlanjut menerpa perekonomian Indonesia. Banyak dari kalangan yang menilai krisis tersebut merupakan akar dari munculnya krisis multidimensi saat ini. Keadaan ini memiliki dampak yang cukup signifikan pada penurunan kinerja ekspor berbagai produk. Banyak usaha berskala besar yang mengalami stagnasi, bahkan collaps. Namun, di sisi lain, Usaha Kecil dan Menengah (UMKM) justru semakin eksis dan survive di tengah krisis ekonomi yang dialami oleh bangsa ini. Hal ini terlihat dengan bertambahnya jumlah UMKM setiap tahunnya. Pada tahun 2012 Tercatat 
bahwa jumlah UMKM sebanyak 56.539 .560 unit dengan ju mlah ten aga kerja y ang dise rap sebanyak 107.657.509 ji wa. Sedangkan pada tahun 2013 jumlah UMKM meningkat menjadi 57.900.787 u n it, dengan jumlah tenaga kerja sebanyak 114.144.082 Jiwa (www.depkop.go.id).

Eksistensi UMKM yang kian bertambah secara kuantitas, semakin memperkokoh keberadaannya dalam kancah perekonomian Indonesia. Disebutkan bahwa UMKM berperan penting dalam pembangunan dan pertumbuhan ekonomi semua Negara termasuk negara-negara maju. Peranan dan manfaat UMKM sangat dirasakan penting karena karakteristikkarakteristiknya yang membuatnya berbeda dari usaha besar, terutama karena UMKM adalah usaha-usaha yang banyak menyerap tenaga kerja, terdapat hampir di setiap lokasi terutama di pedesaan, lebih mengandalkan bahanbahan baku lokal, dan penyedia utama barang-barang dan jasa kebutuhan pokok masyarakat berpendapatan rendah atau miskin (Tulus, $2009: 2-3$ ).

Meski demikian, pengembangan UMKM bukanlah sesuatu yang mudah untuk dilakukan. Berbagai persoalan yang menjadi kendala untuk pengembangan UMKM di Indonesia. Kondisi ini berujung pada lemahnya daya saing produk UMKM terutama terhadap produk impor. Salah satu persoalan utama yang dihadapi UMKM antara lain keterbatasan infrastruktur dan akses administratif terkait dengan perijinan dan birokrasi serta tingginya tingkat pungutan. Dengan segala persoalan yang ada, pengembangan UMKM yang memiliki potensi cukup besar dalam berkontribusi terhadap pertumbuhan ekonomi nasional menjadi terhambat.

Keinginan untuk mempercepat proses pemberdayaan UMKM dan koperasi memang tidaklah mudah karena banyaknya masalah yang membatasi (menjadi kendala) usaha tersebut antara lain kesulitan akses terhadap permodalan, pasar, teknologi dan informasi, rendahnya kualitas SDM UMKM, belum optimalnya fungsi lembaga pemberdayaan UMKM dan iklim usaha yang belum sepenuhnya berpihak kepada UMKM. Kondisi demikian menyebabkan upaya-upaya yang dilakukan oleh UMKM terlihat masih berjalan di tempat. Untuk mengatasi masalah-masalah tersebut pemerintah telah mengeluarkan 
berbagai program pemberdayaan UMKM. Program penguatan UMKM ini menjadi prioritas Kementerian Negara Koperasi dan UMKM sejak tahun 2000. Salah satu sasaran program tersebut adalah untuk memperbaiki iklim usaha UMKM d an koperasi (Suarja, 2007).

Masalah UMKM kian kompleks ketika dihadapkan pada MEA (Masyarakat Ekonomi ASEAN) yang terealisasi pada akhir tahun ini (tahun 2015). ${ }^{2}$ Hal yang menjadi perdebatan dan pertanyaan adalah apakah UMKM kita mampu bersaing di pasar internasional atau setidaknya $\mathrm{ma} \mathrm{m} \mathrm{pu}$ bertahan $\mathrm{d} i$ pasar dalam domestik menghadapi perdagangan yang semakin ketat. Perdebatan ini semakin sengit terutama sejak diberlakukannya China A S E A N Free Trade Area (CAFTA) pada tah un 2010 dan Masyarakat Ekonomi ASEAN (MEA) pada akhir tahun 2015 nanti. Dengan diberlakukannya CAFTA dan MEA $\mathrm{m}$ a $\mathrm{k}$ a tidak ada lagi $\mathrm{h}$ ambatan $\mathrm{t}$ e rhadap arus barang $d$ an $\mathrm{j}$ a sa, $\mathrm{m}$ a $\mathrm{n}$ u s ia $\mathrm{d}$ an modal antara negaranegara anggota ASEAN dan China (Sartono, 2010).

Pemberlakuan CAFTA berdampak pada banjirnya produkproduk China di pasaran Indonesia. Para pakar ekonomi berbeda pendapat mengenai masalah ini. Menurut Sartono, dengan terbentuknya CAFTA akan semakin membuka peluang bagi pengusaha Indonesia dengan alasan dapat memperluas jangkauan pasarnya. Para Pakar Ekonomi j u ga s epakat b ahwa akan s emakin t e rbuka le b ar p eluang in v e stasi, peningkatan volume perdagangan. Pendapat sebaliknya disampaikan oleh Rusdin bahwa salah satu kritik globalisasi adalah meningkatnya ketergantungan antara ekonomi global. Kekuatan ekonomi yang menggantikan dominasi pemerintah akan memfokuskan ke arah perdagangan bebas (free trading). Ketika dunia

MEA at au Masyarakat Ekonomi ASEAN merupakan implikasi dari bidang e konomi yang menjadi salah satu dari tiga pilar (Ekonomi, Sosial Budaya dan Politik Keamanan) yang telah disepakati pada KTT ASEAN ke-9 tahun 2003 dalam Bali Concord II. Sesuai dengan pilar utama MEA ini, akan tercipta pasar tunggal di wilayah ASEAN. Pasar tunggal ini akan munculkan aliran perdagangan barang, jasa, modal dan investasi secara bebas. Indonesia sebagai anggota ASEAN yang mempunyai jumlah penduduk paling banyak akan sangat berpotensi menjadi pasar yang kuat untuk perdagangan barang dan jasa yang dihasilkan oleh negara-negara di ASEAN. 
in i menjadi satu $p$ asar $h$ al in i berakibat menjadi s emakin kuatnya Interdependensi atau saling ketergantungan antara satu negara dengan negara lain. Jadi yang ada sebenarnya adalah bukan satu negara tergantung pada negara lain melainkan situasi dan kondisi di mana semua saling memerlukan dalam rangka pemenuhan kepentingan masing-masing negara (Rusdin, $2002: 34$ ).

Atas dasar tersebut, untuk dapat meningkatkan ketahanan dan keamanan perekonomian Indonesia di masa mendatang, pemerintah perlu kiranya mengeluarkan kebijakan untuk memberikan perhatian yang lebih kepada UMKM agar UMKM ini dapat berkembang dan maju pesat sesuai dengan kapasitasnya yang $\mathrm{s}$ angat $\mathrm{b}$ erharga $\mathrm{b}$ agi perekonomian nasional. UMKM yang tumbuh dengan baik berdampak positif terhadap masalah social ekonmi bangsa ini seperti rendahnya minat investasi, kemiskinan, pengangguran, dan perekonomian dengan biaya tinggi.

Berbagai permasalahan UMKM dapat diatasi apabila pemerintahan diselenggarakan secara bersih, jujur dan bertanggung jawab serta diupayakan secara sunguh-sungguh. Hal ini akan berdampak secara langsung terhadap penurunan ekonomi biaya tinggi, baik yang terjadi di pemerintahan maupun di tingkat pelaku UMKM, termasuk pengusaha dengan skala kecil dan menengah.

Pengembangan UMKM perlu menjadi perhatian yang serius dari semua elemen bangsa, baik dari pemerintah maupun masyarakat luas agar UMKM Indonesia dapat lebih kompetitif bersama pelaku ekonomi lainnya. Kebijakan pemerintah perlu diupayakan lebih mendukung tumbuh dan kembangnya UMKM. Pemerintah juga diharapkan terus meningkatkan perannya dalam memberdayakan UMKM di samping membangun kemitraan usaha yang saling menguntungkan antara pengusaha besar dengan pengusaha kecil, dan meningkatkan kualitas sumber daya manusianya.

Perdagangan yang semakin ketat sebagai akibat dari Implementasi MEA ini akan berdampak pada kelangsungan UMKM, karena akan banyak produk-produk asing yang akan membanjiri pasar dalam negeri ini. Apabila UMKM tidak melakukan pembenahan dan mempertahankan keberadaannya 
guna menghadapi pasar global, maka sangat mungkin banyak UMKM yang akan gulung tikar. Oleh karena itu, kreativitas dan inovasi melalui dukungan penelitian dan pengembangan menjadi sangat penting untuk diperhatikan. Selain itu UMKM harus mampu memanfaatkan peluang untuk meraih potensi pasar dan menjaga eksistensi UMKM dengan baik. Tantangan terbesar bagi UMKM dalam menghadapi MEA adalah bagaimana menentukan strategi guna memenangkan persaingan. Salah satu strategi awal dalam meningkatkan daya saing sebuah kelompok UMKM adalah dengan pendekatan klaster.

Konsep klaster menekankan pada kerjasama antara unsur- unsur yang tergabung di dalamnya di mana unit usaha inti berperan sebagai gerbong penghela klaster atau pemimpin trayektori perkembangan. Pendekatan klaster merupakan pendekatan yang sistematik dalam upaya mengembangkan UMKM. Pendekatan ini tidak mudah dilakukan karena memerlukan berbagai persyaratan. Namun demikian pendekatan ini dapat dilakukan secara bertahap dan berkesinambungan serta konsisten. Konsekuensi logis dari pendekatan ini adalah bahwa komoditi yang diusahakan benar-benar terpilih, paling tidak punya keunggulan komparatif, sumber daya manusia yang berkualitas, serta sarana dan prasarana pendukung yang memadai.

Seiring dengan peningkatan permintaan, persaingan antar perusahaan juga semakin meningkat. Perusahaan harus mempunyai keunggulan kompetitif (Competitive Advantage) untuk dapat terus berkembang dan memenangkan persaingan. Untuk memperoleh keunggulan kompetitif maka suatu perusahaan harus mempunyai sesuatu yang tidak dimiliki oleh pesaing, melakukan sesuatu yang lebih baik dari perusahaan lain, atau mampu melakukan sesuatu yang tidak mampu dilakukan oleh perusahaan lain Dengan demikian, keunggulan kompetitif menjadi suatu kebutuhan penting bagi sukses jangka panjang dan kelangsungan hidup perusahaan (Mudrajat, 2005 : 14).

\section{B. Tinjauan Umum Usaha Mikro, Kecil, dan Menengah (UMKM) di Indonesia}

Usaha Mikro Kecil dan Menengah (UMKM) merupakan salah satu bidang yang memberikan kontribusi yang segnifikan 
dalam memacu pertumbuhan ekonomi Indonesia. Hal ini dikarenakan daya serap UMKM terhadap tenaga kerja yang sangat besar dan dekat dengan rakyat kecil. Statistik pekerja Indonesia menunjukan bahwa 99,5 \% tenaga kerja Indonesia bekerja di bidang UMKM. Hal ini sepenuhnya disadari oleh pemerintah, sehingga UMKM termasuk dalam salah satu fokus program pembangunan yang dicanangkan oleh pemerintah Indonesia. Kebijakan pemerintah te rhadap U M KM $\mathrm{d}$ i tuangkan d alam s ejumlah Undang-undang dan peraturan pemerintah (Jaidan, 2010 : 160).

UMKM merupakan sumber kehidupan ekonomi dari sebagian besar rakyat dan tersebar di seluruh daerah, desa dan kota, serta meliputi hampir seluruh jenis lapangan usaha yang ada. Ketangguhan UMKM sebagai salah satu pilar yang dapat menopang perekonomian bangsa telah terbukti, karena sektor ini mampu bertahan hidup dan bersaing di tengah krisis ekonomi. Keunggulan UMKM dibuktikan pasca kerusuhan Mei 1998 di mana UMKM mampu bertahan sampai sekarang sebagai penyelamat perekonomian nasional. Sementara bidang usaha lain justru tiarap dan porak-poranda dan bahkan gulung tikar. UMKM merupakan jenis usaha yang memiliki daya tahan dan fleksibilitas yang baik dalam menghadapi dinamika kehidupan ekonomi suatu negara (Prihatin, 2001 : 87-88).

Di Indonesia, terdapat berbagai definisi yang berbeda mengenai UMKM berdasarkan kepentingan lembaga yang memberi definisi, di antaranya (Syukriah, 2013):

a. Badan Pusat Statistik (BPS)

UMKM adalah perusahaan atau ind ustri d engan pekerja antara5-19 orang temasuk pemilik usaha atau pengusaha.

b. Bank Indonesia (BI)

UMKM adalah perusahaan atau industri dengan karakteristik berupa: (a) modalnya kurang dari Rp. 20 juta; (b) untuk satu putaran dari usahanya hanya membutuhkan dana Rp 5 jut; (c) memiliki aset maksimum Rp 600 juta di luar tanah dan bangunan; dan (d) omzet tahunan $\leq \mathrm{Rp} 1$ miliar.

c. Departemen (S e k arang Kantor Menteri N egara) Ko p erasi d an U s aha Kecil Menengah (UU No. 9 Tahun 1995): 
UMKM adalah kegiatan ekonomi rakyat berskala kecil dan bersifat tradisional, dengan kekayaan bersih $\mathrm{Rp} 50$ juta - Rp. 200 Juta (tidak termasuk tanah dan bangunan tempat usaha) dan omzet tahunan $\leq \mathrm{Rp} 1$ miliar; dalam UU UMKM/ 2008 dengan kekayaan bersih Rp 50 juta - Rp 500 juta dan penjualan bersih tahunan Rp 300 juta - Rp 2,5 miliar.

d. Keppres No. 16/ 1994

UMKM adalah perusahaan yang memiliki kekayaan bersih maksimal Rp. 400 juta.

e. Departemen Perindustrian dan Perdagangan:

Perusahaan memiliki aset maksimal Rp 600 juta d i lu a r ta $\mathrm{n}$ ah dan bangunan (Departemen Perindustrian sebelum digabung)

Dari persepsi dunia, UMKM memainkan suatu peran yang sangat vital dalam pembangunan dan pertumbuhan ekonomi, tidak hanya di Negara Sedang Berkembang (NSB), tetapi juga di negara-negara maju (NM). Peran UMKM sangat penting tidak hanya karena kelompok usaha tersebut menyerap paling banyak tenaga kerja dibandingkan Usaha Besar (UB), tetapi karena peran UMKM diakui sangat urgen karena karakteristik-karakteristik utama mereka yang membedakan dengan UB, yaitu sebagai berikut (Tulus, 2009 : 2-4):

a. Jumlah perusahaan sangat banyak dibanding UB, terlebih dari kategori usaha mikro (UMI) dan usaha kecil (UK). UMI dan UK tersebar diseluruh pedesaan, maka bisa dikatakan bahwa kemajuan pembangunan ekonomi perdesaan sangat ditentukan oleh kemajuan pembangunan UMKM.

b. UMKM merupakan usaha-usaha padat karya yang mempunyai potensi dan kesempatan pertumbuhan kerja yang sangat besar, pertumbuhan UMKM dapat dimasukkan sebagai suatu elemen penting dari kebijakan kebijakan $\mathrm{n}$ asional untuk meningkatkan k esempatan k erja dan menciptakan pendapatan terutama bagi masyarakat miskin.

c. Pada umumnya mayoritas UMKM terutama UMI di NSB yang berlokasi dipedesaan, kegiatan-kegiatan 
produksinya berbasis pada pertanian. Maka upaya pemerintah UMKM sekaligus merupakan suatu cara tidak langsung, tetapi efektif untuk membangun dan menumbuhkan produksi di sektor pertanian.

d. UMKM memakai teknologi-teknologi yang lebih "cocok" terhadap proporsi-proporsi dari fa kt o r-faktor p roduksi d ari k o n d i s i lo kal yang ada di NSB, yaitu Sumber Daya Alam (SDA) dan tenaga kerja berpendidikan rendah yang berlimpah.

e. Banyak UMKM bisa tumbuh pesat. Bahkan, banyak UMKM yang dapat bertahan pada saat ekonomi Indonesia dilanda suatu krisis besar pada tahun 1997/1998.

f. UMKM dapat menjadi suatu titik permulaan bagi mobilitas tabungan/investasi dipedesaan. Sementara pada waktu yang sama, kelompok usaha ini dapat berfungsi sebagai tempat pengujian dan peningkatan kemampuan berwirausaha dari orang-orang desa.

g. UMKM memainkan suatu peran penting lainnya, yaitu sebagai suatu alat untuk mengalokasikan tabungantabungan perdesaan.

h. Pasar pangsa utama UMKM ditujukan untuk masyarakat kelas menengah ke bawah. Sebagian banyak dari UMKM mampu meningkatkan produktivitasnya lewat investasi dan perubahan teknologi. Satu keunggulan dari UMKM adalah tingkat fleksibilitas yang tinggi dan relative terhadap persaingannya (UB).

\section{Masalah dan Tantangan UMKM di Indonesia}

Sejumlah persoalan yang umum untuk semua UMKM di semua negara manapun, khususnya di NSB, yaitu sebagai berikut (Tulus, 2009 2-4):

1) Keterbatasan modal kerja maupun investasi

2) Kesulitas dalam akses pemasaran

3) Kesulitan dalam aksesdistribusi dan pengadaan bahan baku

4) Keterbatasan akses Informasi mengenai peluang pasar

5) Rendahnya kualitas sumber daya manusia

6) Kesulitan biaya tranportasi

7) Keterbatasan komunikasi

8) Biaya yang tinggi dalam pengurusan izin usaha 
9) Ketidakpastian peraturan dan kebijakan pemerintah dalam masalah ekonomi.

Masalah dasar yang dihadapi UMKM menurut Kurniawan adalah (Mudrajat, 2010 : 196):

1) Kelemahan dalam memperoleh peluang pasar $d$ an memperbesar pangsa pasar

2) Kelemahan dalam struktur permodalan $d$ an keterbatasan untuk memperoleh jalur terhadap sumbersumber permodalan.

3) Kelemahan di bidang organisasi dan manajemen sumber daya manusia.

4) Keterbatasan ja ringan u saha kerjasama antar pengusaha kecil (sistem informasi pemasaran).

5) Iklim usaha yang kurang kondusif, karena persaingan yang saling mematikan.

6) Pembinaan yang telah dilakukan masih kurang terpadu dan kurangnya kepercayaan serta kepedulian masyarakat terhadap usaha kecil.

Masalah UMKM di Indonesia bisa dikelompokkan menjadi dua jalur, yakni internal dan eksternal, adapun perinciannya adalah sebagai berikut (Jaidan, 2010 : 161-162):

1. Faktor Internal

a. Kurangnya Permodalan

Permodalan merupakan faktor utama yang diperlukan untuk mengembangkan suatu unit usaha. Kurangnya permodalan UMKM, oleh karena pada umumnya usaha kecil dan menengah merupakan usaha perorangan atau perusahaan yang sifatnya tertutup, yang mengandalkan pada modal dari si pemilik yang jumlahnya sangat terbatas, sedangkan modal pinjaman dari bank atau lembaga keuangan lainnya sulit diperoleh, karena persyaratan secara administratif dan teknis yang diminta oleh tidak dapat dipenuhi.

b. Sumber Daya Manusia (SDM) yang Terbatas

Sebagian besar usaha kecil tumbuh secara tradisional dan merupakan usaha keluarga yang turun temurun. Keterbatasan SDM usaha kecil baik 
dari segi pendidikan formal maupun pengetahuan keterampilannya sangat berpengaruh terhadap manajemen pengelolaan usahanya, sehingga usaha tersebut sulit untuk berkembang dengan optimal.

Di samping itu dengan keterbatasan SDM-nya, unit usaha tersebut relatif sulit untuk mengadopsi perkembangan teknologi baru untuk meningkatkan daya saing produk yang dihasilkannya.

c. Lemahnya Jaringan Usaha dan Kemampuan Penetrasi Pasar

Usaha kecil yang pada umumnya merupakan unit usaha keluarga, mempunyai jaringan usaha yang sangat terbatas dan kemampuan penetrasi pasar yang rendah, oleh karena produk yang dihasilkan jumlahnya sangat terbatas dan mempunyai kualitas yang kurang kompetitif. Berbeda dengan usaha besar yang telah mempunyai jaringan yang sudah solid serta didukung dengan teknologi yang dapat menjangkau internasional dan promosi yang baik.

2. Faktor Eksternal

a. Iklim Usaha Belum Sepenuhnya Kondusif

Kebijaksanaan Pemerintah untuk menumbuhkembangkan UMKM, meskipun dari tahun $\mathrm{ke}$ tahu $\mathrm{n}$ te rus disempurnakan, namun dirasakan belum sepenuhnya kondusif. Hal ini terlihat antara lain masih terjadinya persaingan yang kurang sehat antara pengusaha-pengusaha kecil dengan pengusaha-pengusaha besar.

b. Terbatasnya Sarana dan Prasarana Usaha

Kurangnya informasi yang berhubungan dengan kemajuan ilmu pengetahuan dan teknologi, menyebabkan sarana dan prasarana yang mereka $m$ iliki juga tidak cepat berkembang dan kurang mendukung kemajuan usahanya sebagaimana yang diharapkan.

c. Implikasi Otonomi Daerah

Dengan berlakunya Undang-undang No. 22 Tahun 1999 tentang Otonomi Daerah, kewenangan 
daerah mempunyai otonomi untuk mengatur dan mengurus masyarakat setempat. Perubahan sistem ini akan mengalami implikasi terhadap pelaku bisnis kecil dan menengah berupa pungutan-pungutan baru yang dikenakan pada UMKM. Jika kondisi ini tidak segera dibenahi maka akan menurunkan daya saing UMKM. Di samping itu semangat kedaerahan yang berlebihan, kadang menciptakan kondisi yang kurang menarik bagi pengusaha luar daerah untuk mengembangkan usahanya di daerah tersebut.

d. Implikasi Perdagangan Bebas

UMKM harus mempersiapkan kualitas produk untuk mampu bersaing dengan produk import ketika menghadapi persaingan bebas. Maka disini dibutuhkan kreativitas dan inovasi bagi pelaku usaha untuk tetap dapat berkarya dengan produknya.

e. Sifat Produk Dengan Lifetime Pendek

Sebagian besar produk industri kecil memiliki ciri atau karakteristik sebagai produk produk fasion dan kerajinan dengan lifetime yang pendek.

f. Terbatasnya Akses Pasar

Terbatasnya akses pasar akan menyebabkan produk yang dihasilkan tidak dapat dipasarkan secara kompetitif baik di pasar nasional maupun internasional. Memang cukup berat tantangan yang harus dihadapi UMKM untuk memperkuat srtuktur perekonomian $\mathrm{n}$ asional. T a $\mathrm{n} t$ angan yang yang dihadapi UMKM d apat d ibagi dalam d u a k ategori sebagai berikut (Kuncoro, 2010 : 196-197):

1) Bagi usaha dengan omzet kurang 300 juta per tahun umumnya tantangan yang dihadapi adalah bagaimana menjaga kelangsungan hidup usahanya, Mereka cukup memerlukan modal sekedar membantu kelancaran cash flow saja.

2) Bagi usaha dengan omzet antara 300 juta hingga 2,5 milliar per tahun tantangan yang dihadapi jauh lebh komplek. Berdasarkan pengamatan Pusat Konsultasi Pengusaha kecil UGM, urutan priortas permasalahan yang dihadapi oleh usaha jenis ini adalah: 
a. Masalah belum ada b elum adanya system administrasi keuangan dan manajemen yang baik karena belum dipisahkannya kepemilikannya dan pengelolaan perusaahaan.

b. Masalah bagaimana menyusun proposal dan membuat studi kelayakan untuk memperoleh pinjaman, baik dari bank maupun dari ventura karena kebanyakan UMKM mengeluh berbelitnya prosedur mendapatkan kredit aguna tidak memenuhi syarat, dan tingkat bunga dinilai terlalu tinggi.

c. Masalah menyusun perencanaan bis $\mathrm{n}$ is karena persaingan d alam merebut pasar semakin ketat.

d. Masalah akses terhadap teknologi terutama bila pasar dikuasai oleh perusahaan atau group bisnis tertentu dan selera konsumen cepat berubah.

e. Masalah memperoleh bahan baku karena adanya persaingan yang ketat dalam mendapatkannya, bahan baku berkualitas rendah, dan tingginya harga bahan baku.

f. Masalah perbaikan kualitas barang dan efisiensi terutama bagi yang sudah menggarap pasar ekspor karena selera konsumen cepat berubah, pasar d i k u a s ai p erusahaan tertentu, $d$ an $b$ anyak $b$ arang pengganti.

g. Masalah tenaga kerja karena sulit mendapatkan tenaga kerja yang terampil.

UMKM di negara kita mengalami kendala dan masalah yang cukup rumit dilihat dari aspek internal maupun eksternal. Namun, di balik tantangan yang berat ternyata masih banyak peluang yang sangat besar. Hal ini sangat tergantung pada bagaimana kita mampu menggali dari potensi yang ada tersebut.

Di kawasan Asia dan Pasifik ada APEC, di mana Indonesia baru akan bergabung dalam perdagangan dan investasi bebas pada tahun 2020. Kawasan perdagangan dan investasi regional ini dapat dimanfaatkan untuk mengembangkan potensi bisnis bagi koperasi. Tentu hal ini sangat tergantung pada kelihaian koperasi dalam memanfaatkan potensi yang ada tersebut (Dipta, 2012 : 10).

Di samping peluang pasar domestik dan regional tersebut, 
belakangan beberapa negara baik di Asia dan kawasan Asia dan Pasifik menyadari pentingnya pembentukan kawasankawasan baru. Untuk kawasan ASEAN, selain ASEAN plus three, yaitu ASEAN, China, Korea Selatan dan Jepang, juga telah berkembang antara ASEAN dengan Australia dan New Zealand, ASEAN+US, dan sebagainya. Secara perlahan tapi pasti pada kawasan baru ini akan terjadi kesepakatan untuk melakukan liberalisasi dalam bidang perdagangan dan investasi.

\section{Persaingan Bebas Masyarakat Ekonomi ASEAN (MEA)}

Masyarakat Ekonomi Asean (MEA) atau disebut juga ASEAN Economicy Community (AEC) adalah bentuk integrasi ekonomi ASEAN yang direncanakan akan tercapai pada tahun 2015. MEA adalah komunitas ASEAN (ASEAN Community) di bidang Ekonomi atau ASEAN Economic Community (AEC) yang dicanangkan pada Konferensi Tingkat Tinggi (KTT) ASEAN ke-9 di Bali pada tahun 2003, atau dikenal sebagai Bali Co $n$ cord II. Pembentukan komunitas te rsebut diprakarsai oleh p ara Kepala Negara ASEAN pasca krisis ekonomi tahun 1997 di kawasan Asia Tenggara. MEA diharapkan dapat mewujudkan tercapainya suatu kawasan stabil, makmur, berdaya saing tinggi dengan pertumbuhan ekonomi yang berimbang serta berkurangnya kemiskinan dan kesenjangan sosial ekonomi. Bali Concord II tidak hanya menyepakati pembentukan MEA, namun juga menyepakati pembentukan komunitas ASEAN di bidang Keamanan Politik (ASEAN Political-Security Community) dan Sosial Budaya (ASEAN Socio Culture Community) (Syukriah, 2013 : 112).

Untuk mewujudkan MEA pada tahun 2015, sebagaimana kesepakatan dalam Bali Concord II, telah disusun ASEAN Economic Community (AEC) Blueprint sebagai pedoman bagi negara-negara anggota ASEAN. Empat pilar utama dalam AEC Blueprint yaitu: (1) ASEAN sebagai pasar tunggal dan berbasis produksi tunggal yang didukung dengan elemen aliran bebas barang, jasa, investasi, tenaga kerja terdidik dan aliran modal yang lebih bebas; (2) ASEAN sebagai kawasan dengan daya saing tinggi, dengan elemen peraturan kompetisi, perlindungan konsumen, hak atas kekayaan intelektual, pengembangan infrastruktur, perpajakan dan e-commerce; (3) 
ASEAN sebagai kawasan dengan pengembangan ekonomi yang merata dengan elemen pengembangan usaha kecil dan menengah serta pemrakarsa integrasi ASEAN $\mathrm{u} n \mathrm{tuk}$ negara-negara CMLV (Cambodia, Myanmar, Laos dan Vietnam); dan (4) ASEAN sebagai kawasan yang terintegrasi secara penuh dengan perekonomian global dengan elemen pendekatan yang koheren dalam hubungan ekonomi di $\mathrm{l} u$ a $\mathrm{r}$ kawasan $\mathrm{d}$ an m e n i n gkatkan peran s erta d alam j e jaring p roduksi global.

Beberapa indikator yang digunakan untuk mengukur d aya saing sebuah produk diantaranya adalah:

1) Pangsa ekspor per tahun (\% dari jumlah ekspor).

2) Pangsa pasar luar negeri per tahun (\%)

3) Laju pertumbuhan ekspor per tahun (\%)

4) Pangsa pasar dalam negeri per tahun (\%)

5) Laju pertumbuhan produksi per tahun (\%)

6) Nilai atau harga produk

7) Diversifikasi pasar domestic

8) Diversifikasi pasar ekspor, dan

9) Kepuasan konsumen (Susilo, $2010: 72$ ).

Pembentukan Komunitas ASEAN 2015 berlandaskan pada

3 pilar, yaitu Komunitas Keamanan ASEAN (ASEAN Security Community), Komunitas Ekonomi ASEAN (ASEAN Economic Community), dan Komunitas Sosial Budaya ASEAN (ASEAN Socio-Cultural Community). Komunitas E k o n o m i ASEAN (ASEAN E conomic Com munity/AEC) 2015, akan diarahkan kepada pembentukan sebuah integrasi ekonomi kawasan dengan mengurangi biaya transaksi perdagangan, memperbaiki fasilitas perdagangan dan bisnis, serta meningkatkan daya saing sektor UMKM (Kementerian Koperasi dan UKM, Http://Depkop. Go.Id/Index).

Pemberlakuan AEC 2015 bertujuan untuk menciptakan pasar tunggal dan basis produksi yang stabil, makmur, berdaya saing tinggi, dan secara ekonomi terintegrasi dengan regulasi efektif untuk perdagangan dan investasi, yang di dalamnya terdapat arus bebas lalu lintas barang, jasa, investasi, dan modal serta difasilitasinya kebebasan pergerakan pelaku usaha dan tenaga kerja. Implementasi AEC 2015 akan berfokus pada 12 sektor prioritas, yang terdiri atas 7 (tujuh) sektor barang (industri pertanian, peralatan elektonik, otomotif, perikanan, 
industri berbasis karet, industri berbasis kayu, dan tekstil) dan 5 (lima) sektor jasa (transportasi udara, pelayanan kesehatan, p ariwisata, logistik, dan industri teknologi informasi atau e-ASEAN). Kementerian Ko perasi d an UM KM m em i liki concern dan komitmen dalam mendukung $\mathrm{u} p$ aya $\mathrm{m}$ e ngantisipasi pelaksanaan MEA melalui koordinasi, sinkronisasi, sinergi dan kerjasama mulai dari aspek hulu, middle dan hilir dalam kerangka pemberdayaan pemberdayaan Koperasi dan UMKM.

Sebagai satu pasar dan basis produksi, AEC bermakna liberalisasi aliran $\mathrm{b}$ arang, jasa, investasi, modal, dan tenaga kerja terampil. Boleh dikatakn AEC adalah AFTA plus. Dengan kawasan perdagangan bebas ASEAN (AFTA), berbagia hambatan perdagangan, baik bea maupun(tarriffs) maupun nonbea masuktelah dihapus dan diturunkan.selain itu,fasilitas aliran barang perdagangan dilakukan dengan mengintegrasikan produsen pabean dengan apayang disebut ASEAN Single Window, termasuk prosedur sertifikasi operasional, harmonisasi standar dan prosedur.

Untuk mempertahankan eksistensinya, sebuah UMKM pada pergolakan perdagangan bebas sekarang ini, harus membutuhkan suatu strategi salah satunya dengan penggabungkan pendekatan strategi klaster industri dan juga dengan memanfaatkan sumber daya (Resource-Based View atau $R B V$ ) yang ada $\mathrm{p}$ ada UMKM tersebut sebagai bentuk untuk menciptakan kunggulan kompetitif.

Menurut model Berbasis Sumber Daya (Resouce-Based View atau RBV), Model ini menfokuskan pada pengembangan atau perolehan sumber daya (resources) dan kapabilitas (abilities) yang berharga, yang sulit atau tidak mungkin ditiru oleh para pesaing. Sehingga dengan begitu UMKM tidak perlu khawatir masalah yang akan muncul ketika dihadapkan pada implementasi Masyarakat Ekonomi ASEAN (MEA) nanti.

\section{E. Strategi Meningkatkan Daya Saing UMKM a. Pengertian Daya Saing}

Perusahaan yang tidak mempunyai daya saing akan ditinggalkan oleh pasar. Karena tidak memiliki daya saing berarti tidak memiliki keunggulan, dan tidak unggul berarti 
tidak ada alasan bagi suatu perusahaan untuk tetap survive di dalam pasar persaingan untuk jangka panjang. Daya saing berhubungan dengan bagaimana efektivitas suatu organisasi di pasar persaingan, dibandingkan dengan organisasi lainnya yang menawarkan produk atau jasajasa yang sama atau sejenis. Perusahaan-perusahaan yang mampu menghasilkan produk atau jasa yang berkualitas baik adalah perusahaan yang efektif dalam arti akan mampu bersaing.

"Competition is at the core of the success or failure of firms" atau persaingan adalah inti dari kesuksesan atau kegagalan perusahaan. Terdapat dua sisi yang ditimbulkan oleh persaingan, yaitu sisi kesuksesan karena mendorong perusahaan-perusahaan untuk lebih dinamis dan bersaing dalam menghasilkan produk serta memberikan layanan terbaik bagi pasarnya, sehingga persaingan $\mathrm{d}$ i anggapnya sebagai peluang yang memotivasi. Sedangkan sisi lainnya adalah kegagalan karena akan memperlemah perusahaan-perusahaan yang bersifat statis, takut akan persaingan dan tidak mampu menghasilkan produkproduk yang berkualitas, sehingga persaingan merupakan ancaman bagi perusahaannya.

Daya saing global yang rendah dari UMKM secara di NSB dapat menjadi suatu hambatan serius bagi kelompok usaha tersebut buk an saja untuk menembus pasar global, tetapi juga untuk bisa memenangi persaingan dengan barang-barang impor di pasar domestik. Maka strategi yang harus dilakukan oleh sebuah perusahaan untuk meningkatkan daya saingnya terdiri dari dua (2) komponen atau sub-strategi. Komponen pertama, strategi untuk memenuhi/pengadaan kelima prasyarat utama tersebut. Pertanyaannya disini adalah: bagaimana pengadaan pendidikan, modal, teknologi, informasi dan input secara kontinu dan efisien? Komponen kedua, strategi untuk menggunakan secara optimal kelima prasyarat tersebut menjadi suat u p roduk yang kompetitif (Tulus, 2009: 91).

\section{b. Keunggulan Kompetitif}


Suatu perusahaan dikatakan memiliki keunggulan kompetitif ketika perusahaan tersebut memiliki sesuatu yang tidak dimiliki oleh pesaing. Kunggulan kompetitif adalah segala sesuatu yang dilakukan dengan sangat baik oleh perusahaan dibandingkan dengan yang dilakukan oleh pesaingnya (Husni, 2009 : 145).

Ada 2 teori keunggulan kompetitif di dalam literatur manajemen strategi yang selama ini banyak diikuti oleh para peneliti, yaitu teori berbasis Industrial Organization (I/O) yang disebut sebagai outside-in dan teori berbasis sumber daya (Resource-Based View atau RBV) yang disebut sebagai inside-out. IK (Industri Kecil) berada pada lingkungan usaha yang sangat tidak pasti, maka sangat sulit bagi IK untuk menerapkan pendekatan I/O untuk merencanakan strateginya karena akan memerlukan perencanaan strategi terus menerus mengikuti kondisi lingkungan yang tidak pasti tersebut.

Sedangkan untuk mendayagunakan sumber daya yang dimilikinya (sesuai dengan pendekatan $R B V$ ) akan lebih mudah bagi IK karena yang dibutuhkan adalah kapabilitas dalam pendayagunaan sumber $\mathrm{d}$ aya tersebut yaitu kapabilitas personal $m$ anajer pemilik. Dengan pertimbangan-pertimbangan tersebut maka secara teoritis pendekatan $R B V$ lebih sesuai untuk diterapkan di IK. Penelitian ini menggunakan konsep $R B V$ sebagai pendekatan teoritis keunggulan kompetitif (Widjajani, 2008 :51).

Menurut pendekatan $R B V$, keunggulan kompetitif dapat diciptakan jika perusahaan secara efektif dapat mengidentifikasi, mengembangkan dan mendayagunakan sumber daya strategisnya untuk memaksimasi pendapatan. Sedangkan untuk dapat mengidentifikasi, mengembangkan dan mendayagunakan sumber daya strategisnya guna memperoleh keunggulan kompetitif, suatu perusahaan harus memiliki sifat entrepreneurial, yaitu $\mathrm{k}$ ecenderungan u n t uk menghadapi ris iko, inovasi dan sikap proaktif (Miller, 1983 : 770-791).

Keunggulan kompetitif akan diperoleh perusahaan yang memiliki aset dan kapabilitas yang khas dan bisa 
mengaitkan kapabilitas internal perusahaan dengan apa yang diminta pasar dan ditawarkan pesaing. Profitabilitas ditentukan oleh jenis dan sumber daya yang unik serta kapabilitas yang khas.

Beberapa aset sumber daya (Resource-Based View atau $R B V$ ) kunci tertentu akan memberikan perusahaan keunggulan kompetitif yang berkelanjutan. Walaupun sebuah perusahaan akan berhasil jika memiliki sumber daya yang paling sesuai dan paling baik untuk usaha dan strateginya. Akan tetapi apabila pesaing dapat saling meniru, maka keunggulan kompetitif yang berkelanjutan tidak dapat diperoleh sehingga keuntungan di atas rata-rata tidak dapat dicapai (Kuncoro, 2003 : 14-18).

Menurut Pendekatan $R B V$ ada tiga sumber daya yang harus dijaga oleh perusahaan karena merupakan fondasi utama dari sebuag perusahaan, yaitu (Pearce, 2009 : 39):

1. Aset yang terlihat (tangible asset) adalah aset yang paling mudah diidentifikasi dan sering ditemukan pada neraca perusahaan. Yang termasuk dalam asei ini adalah fasilitas produksi, bahan mentah, sumber daya financial, asset real, dan computer.

2. Aset yang tak terlihat (intangible as set), yang termasuk jenis aset ini adalah merek, reputasi, moral organisasi, pengetahuan teknis, hak paten, merk dagang, dan akumulasi pengalaman dari suatu perusahaan.

3. Kapabilitas organisasi bukan termasuk input yang spesifik sebagaimana aset terlihat, melainkan keahlian berupa kemampuan dan cara mengkombinasi aset, manusoa dan proses yang dapat dimanfaatkan oleh perusahaan untuk mengubah input menjadi output.

\section{c. Unsur-unsur $R B V$}

\section{Kapabilitas}

Kapabilitas adalah keahlian berupa kemampuan dan cara mengkombinasikan aset, tenaga kerja dan proses yang dapat dimanfaatkan oleh perusahaan untuk mengubah input menjadi output. Kapabilitas juga dapat dikatakan sebagai kemampuan perusahaan 
untuk mengintregrasikan sumber daya yang dimilikinya untuk mencapai tujuan yang diinginkan (Husni, 2009 : 50).

\section{Kompetensi Inti}

Kompetensi inti merupakan apa yang dilakukan perusahaan, yang bernilai secara strategik. Esensi kompetensi merupakan hal yang membuat perusahaan menjadi unik dalam hal k emampuannya me nawarkan nilai kepada $\mathrm{p}$ ara pelanggannya. Dengan demikian kompetensi inti adalah nilai utama perusahaan dalam menciptakan keahlian dan kapabilitas yang disebarkan melalui bermacam garis produksi ataupun bisnis (Pearce, 2009 : 78).

\section{Analisis Lingkungan Perusahaan}

Dalam memperoleh keunggulan kompetitif, menurut Porter perusahaan harus mampu mengidentifikasi lingkungan perusahaan yang sering berubah-ubah setiap saat. Analisis lingkungan perlu dilakukan sesuai dengan general system theory, yaitu " organisasi merupakan sistem terbuka, dan organisasi modern secara kontinyu berinteraksi dengan lingkungannya." Struktur lingkungan biasanya dibagi menjadi tiga bagian, yaitu (Tedjo, 2005 : 106-107):

\section{General Environment (lingkungan Umum atau} lingkungan internal)

General Environment adalah komponenkomponen diluar organisasi yang tidak memiliki hubungan langsung dengan manajemen praktis. Lingkungan umum meliputi aspek ekonomi, sosial, politik, legal, dan teknologi.

\section{a. Politik}

Politik merupakan cara dalam membagi dan medapatkan kekuasaan. Tingkatan faktor politik ada tiga yaitu internasional, nasional dan daerah atau lokal. Peran pemerintah dalam ranah politik biasanya karena kebijakan dan peraturan yang mereka tetapkan. Beberapa contoh peran pemerintah dalam faktor politik atara lain : 
1) Kebijakan kesehatan, k etenagakerjaan, bea masuk, inflasi, dan pertumbuhan ekonomi.

2) Pekerjaan pemerintah dan sektor publik.

3) Kebijakan fiskal atau pajak.

4) Kebijakan me ngenai pelestarian lingkungan seperti polusi d an limbah.

b. Ekonomi

Salah satu faktor ekonomi yang cukup berpengaruh adalah nilai tukar mata uang. Hal ini akan berdampak pada perusahaanperusahaan yang mengimpor bahan $b a k u$ dari $1 \mathrm{u}$ arnegeri. Jika ni lai tuk ar dalam negeri menurun maka biaya utuk mendatangkan bahan baku akan jauh lebih besar.

c. Sosial

Faktor sosial tersebut antara lain: Sikap, nilai, kepercayaan, Kebudayaan, dan Demografi. Faktor sosial biasanya langsung berhubungan dengan konsumen atau pelanggan perusahaan.

d. Teknologi

Saat ini perkembangan teknologi sangat berpengaruh terhadap daya saing perusahaan. Perkembangan tenologi yang terjadi sebaiknya terus mendapatkan perhatian seingga perusahaan juga tidak ketinggalan dengan perusahaan lainnya.

5. Internal Environment (Lingkungan Internal)

Internal Environment atau sering kita sebut dengan lingkungan internal adalah komponenkomponen yang datang dari dalam perusahaan itu sendiri. Pendekatan ini berupaya untuk mengidentifikasi dan menilai faktor-faktor internal yang mencakup kemampuan perusahaan, keterbatasan, dan ciri-cirinya yang biasanya dikategorisasikan pada, (1) posisi pasar, (2) keuangan 
dan akunting, (5) produksi yang berarti aspek teknis dan operasional perusahaan), (4) sumber daya manusia, dan (5) struktur organisasi dan manajemen.

\section{F. Klaster Industri}

\section{1) Pendekatan strategi alternalif (Clustering)}

Strategi adalah pendekatan secara keseluruhan yang berkaitan dengan pelaksanaan gagasan, perencanaan, dan eksekusi sebuah aktivitas dalam kurun waktu tertentu. Di dalam strategi yang baikterdapat $\mathrm{k}$ o or dinasi tim k erja, m e mi liki t e ma, men gidentifikasi factor pendukung yang sesuai dengan prinsip-prinsip pelaksanaan gagasan secara rasional, efisien dalam pendanaan, dan memiliki taktik untuk mencapai tujuan secara efektif.

Dengan berkembangnya berbagai bidang ilmu pengetahuan, termasuk teknologi informasi yang maju dengan pesatnya, berdampak pada berbagai aspek kehidupan. Akibatnya, kompetensi dewasa ini menjadi begitu ketat dan dinamis. Peta ekonomi dunia saat ini didominasi oleh klaster (cluster), yaitu konsentrasi geografis dari perusahaan dan institusi yang saling berkaitan dalam bidang tertentu. Klaster mencakup susunan dari industri yang berkaitan dan entitas lainnya yang penting dalam kompetensi (Kuncoro, 2005 :30).

Kacung Marijan berpendapat bahwa terdapat tiga konsep dalam literatur yang berkaitan dengan lokalisasi industri, yaitu klaster industri (cluster industri), industri berbasis daerah (industrial district) dan aglomerasi ekonomi (agglomeration economy). (Marijan, 2005 : 220). Klaster ind ustri sendiri sering dibatasi melalui dua cara yang berbeda. Pertama adalah dibatasi secara fungsional. Klaster industri lebih dipandang sebagai sekelompok perusahaan yang berkaitan dengan kegiatan yang serupa di dalam suatu ekonomi nasional daripada hanya sekadar terletak di dalam lokasi tertentu. Karena itu, faktor yang paling penting di dalam klaster industri 
adalah adanya keterkaitan (linkages) antara perusahaanperusahaan di dalam sektor tertentu atau dengan sektorsektor yang lain tetapi saling mendukung (Marijan, 2005 :220).

Sudah sejak lama bahwa fenomena klaster telah menarik perhatian para ekonom untuk terjun dalam studi masalah lokasi, sehingga memunculkan paradigma baru yang disebut geografi ekonomi baru (new economic geography atau geographical economics). Argumentasi ini dikuatkan oleh fakta bahwa peta ekonomi dewasa ini didominasi oleh apa yang dinamakan klaster (cluster). Hal senada juga ditegaskan oleh Kuncoro bahwa industri cenderung beraglomerasi di daerah-daerah di mana potensi mereka mendapat manfaat akibat lokasi perusahaan yang saling berdekatan (Kuncoro,, $2003: 1$ ).

Dalam kaitannya dengan UMKM, pertumbuhan UMKM mulai menjadi topik yang cukup hangat sejak munculnya tesis flexible specialization pada tahun 1980an, yang didasari oleh pengalaman dari sentra-sentra Industri Skala Kecil (ISK) dan Industri Skala Menengah (ISM) di beberapa negara di Eropa Barat, khus us nya Italia. Sebagai contoh kasus, bahwa pada tahun 1970-80an, pada saat Industri Skala Besar di Inggris, Jerman dan Italia mengalami staknasi atau kelesuan, ternyata Industri Skala Kecil (terkonsentrasi di lokasi tertentu membentuk sentra-sentra yang membuat produk-produk tradisional mengalami pertumbuhan yang pesat dan bahkan mengembangkan pasar ekspor untuk barang-barang tersebut dan menyerap banyak tenaga kerja. Pengalaman ini menunjukkan bahwa industri kecil di sentra-sentra dapat berkembang lebih pesat, lebih fleksibel dalam menghadapi perubahan pasar, dan dapat meningkatkan produksinya daripada industri kecil secara individu di luar sentra (Kuncoro,, $2003: 1)$.

Dengan Karakter klaster yang seperti itu dilihat memiliki potensi di dalam usaha pengembangan ekonomi. Karena itu, pola klaster kemudian menjadi 
Strategi Klaster Industri Menghadapi Pasar Global

salah satu pendekatan (approach) yang menjadi r ekomendasi s ejumlah i lmuwan d an d ipakai ol e h pengambil kebijakan di dalam mengembangkan industri di suatu daerah atau negara. Pendekatan klaster tampaknya merupakan pilihan yang bijaksana bagi pengembangan UMKM di masa mendatang. Dalam penggunaan Pendekatan klaster juga disebut dengan pendekatan yang sistematik dalam upaya mengembangkan UMKM.

Pendekatan klaster ini tidak mudah dilakukan, karena memerlukan berbagai persyaratan, namun demikian pendekatan ini dapat dilakukan secara bertahap dan berkesinambungan serta konsisten. Konsekuensi 1 o gis $\mathrm{d}$ ari pendekatan in i adalah bahwa komoditi yang diusahakan benar-benar terpilih, paling tidak punya keunggulan komparatif, orang-orang yang ada di dalamnya mempunyai kesadaran dan kemauan yang cukup tinggi te rmasuk di dalamnya akhlak yang baik, perlu adanya aglomerasi dan kaitan huluhilir, sarana dan prasarana pendukung yang memadai. Pengembangan jejaring UMKM dilakukan dengan pendekatan klaster yang meliputi (Rafinaldy, 2006):

1. Mengembangkan kriteria untuk menyeleksi p artner ( $p$ asangan) yang memiliki pengalaman dan pengetahuan lokal yang memadai.

2. Mengkaji sistem bis $\mathrm{n}$ is $\mathrm{d}$ an o perasi secara internal setiap pelaku bisnis yang akan dikembangkan.

3. Mengembangkan kurikulum dan materi pelatihan bagi UMKM, broker/pialang bisnis atau konsultan BDS Providers dan dikomunikasikan lewat berbagai media termasuk internet.

4. Merancang skim subsidi yang efisien yang $d$ apat mencegah terjadinya distorsi untuk menutupi biaya awal bagi pialang jejaring bisnis.

5. Menyediakan bantuan teknis bagi setiap UMKM yang bekerjasama.

6. Merancang dan melakukan evaluasi secara 
s eksama setiap u paya pengembangan jejaring bisnis melalui klaster UMKM.

7. Memberikan perhatian dari berbagai usulan kajian yang dilakukan oleh staf, pihak-pihak yang bekerjasama, pialang bisnis termasuk BDS provider dalam penyempurnaan setiap konsep yang akan dikembangkan dalam pengembangan klaster UMKM.

Sejumlah faktor yang menunjukkan klaster-klaster UMKM di Eropa Barat mampu berkembanga pesat, yaitu sebagi berikut (Tulus danTambunan, 2001 : 128-129):

a. Di dalam sentra terdapat juga pemasok bahan baku, alat-alat produksi, mesin, dan ,demikian jarak antara penyediaan input-input tersebut, subkintraktor, dan produsen barang jadi dengan pengusaha UMKM menjadi dekat. Hal ini eslain mengurangi ongkos produksi, juga memperlancar keterkaitan bisnis antar mereka.

b. Adanya suatu kombinasi antara persaingan yang ketat disatu pihak, antar sesama usaha UMKM. Melalui usaha yang intensif antar sesama independen UMKM berdasarkan spesialisasi masing- masing terciptalah suatu tingkat efisiensi yang tinggi (colective efficiency)

c. Di dala klaster-klaster terdapat pusat-pusat pelayanan, terutama yang disediakan oleh pemerintah lokal, yang dapat digunakan secara kolektif oleh semua pengusaha yang ada didalam klaster- klaster.

d. UMKM di dalam klaster menjadi sangat fleksibel dalam menghadapi perubahan-perubahan pasar. Hal ini didukung dari kerjasama atau pembagian tugas yang baik sesuai spesialisasi masing-masing antarsesama pengusaha. Inti dari itu semua adalah network dan inovasi.

\section{2) Unit-unit dalam Klaster}

Klaster merupakan pengelompokan berbagai 
perusahaan pada sektor $\mathrm{u} \mathrm{s}$ a h a yang sama d alam $\mathrm{su}$ a t u wilayah tertentu. Dalam su a t u k la ster terdiri dari perusahaan inti (core industri) yaitu produsen produk utama klaster, industri terkait (related Industries) yaitu usaha penunjang bagi produksi seperti pemasok bahan baku, industri pendukung (supporting industries) dan jasa lainnya yang dalam pengembangannya tidak difokuskan inti saja melainkan secara keseluruhan seperti pedagang perantara.

Kunci keberlangsungan pengembangan klaster yaitu terciptanya kerjasama antara stakeholder dan efisiensi kolektif yang dapat dilakukan pada semua lini tahapan produksi mulai dari penyediaan input produk, proses produksi, pemasaran dan distribusi hingga ke konsumen akhir. Jalinan kerjasama dalam lingkungan usaha klaster memberikan manfaat positif dengan menciptakan rantai nilai produksi yang saling menguntungkan sehingga produktivitas usaha saling dapat ditingkatkan.

\section{3) Keuntungan Klaster}

Dalam pandangan Marshall, sentra-sentra industri itu, yang di dalamnya terdapat industri kecil $d$ an menengah (IKM), telah memperoleh keuntungan karena berada di dalam suatu wilayah yang berdekatan (geographical proximity). Di antaranya adalah tersedianya tenaga kerja yang memiliki ketrampilan khusus dan sangat dibutuhkan oleh perusahaanperusahaan (labour pool) dan adanya pertukaran informasi $\mathrm{d}$ an gagasan (knowledge s p i ll-over).

Keuntungan-keuntungan yang didapat dari kedekatan dengan perusahaan-perusahaan lain itu disebut penghematan eksternal (external economies). Keuntungan demikian berbeda dengan keuntungan akibat penghematan internal (internal economies), yakni penghematan-penghematan biaya yang terjadi di dalam suatu unit perusahaan itu sendiri, termasuk adanya efisiensi.

Dengan memutuskan untuk membangun sebuah 
klaster, diharapkan akan memiliki beberapa manfaat yang dapat diperoleh dari pengembangan klaster industri, diantaranya (Yuli, 2011):

a. Menciptakan manfaat ekonomi dan daya saing.

b. Meningkatkan efisiensi dan produktivitas bagi perusahaan di dalam klaster s erta p eningkatan kemampuan inovasi yang melibatkan lembaga penelitian.

c. Mengurangi biaya transportasi d an transaksi, meningkatkan efisiensi, menciptakan aset secara kolektif dan memungkinkan terciptanya inovasi yang pada akhirnya akan meningkatkan daya saing.

d. Memiliki keunggulan dalam memanfaatkan aset sumberdaya secara kolektif untuk mendorong diversifikasi produk dan meningkatkan terciptanya inovasi.

e. Mendorong terjadinya spesialisasi produksi sesuai dengan kompetensi in ti $d$ an mendorong $t$ ransformasi k eunggulan komparatif menjadi keunggulan kompetitif (Porter : 1998).

Pendekatan strateginya yang tepat adalah melalui clustering, yang berarti program utama peningkatan daya saing UKM (dan koperasi) adalah program pengembangan klaster-klaster (atau sentra-sentra) UKM. Pendekatan clustering ini sudah terbukti di banyak negara seperti di Eropa dan lainnya, pendekatan ini sangat ampuh dalam meningkatkan kemampuan inovasi dan daya saing global dari UKM. Di dalam literatur mengenai pengembangan UKM sudah ada kesepakatan bersama bahwa paling tidak ada tiga keuntungan utama dari pengembangan UKM berdasarkan clustering (Tulus, $2001: 106)$ :

a. UKM lebih mudah mengatasi semua kekurangan/hambatan dalam segala aspek bisnis mulai dari pengadaan bahan baku, proses produksi, distribusi dan pemasaran, pendanaan, perbaikan mesin, dll, dibandingkan jika UKM 
beroperasi sendiri-sendiri. UKM di dalam sebuah klaster akan menikmati apa yang dimaksud dengan "keuntungan ekonomi aglomorasi".

b. Lebih efisien dan efektif dalam pemberian bantuan atau kerjasama antara UKM dengan pihak lain, misalnya, UB dalam kegiatan subcontracting, perbankan dalam penyaluran kredit, dan eksportir, pedagang atau distributor dalam pemasaran. Efek ini disebut juga sebagai "efisensi kolektif".

c. Proses peralihan teknologi/pengetahuan dari sumber luar (misalnya dari perusahaan multinasional; MNCs) ke UKM dan penyebarannya antara sesama UKM lebih gampang, lebih efisien, dan lebih efektif di dalam sebuah klaster dibandingkan jika unit- unit UKM sangat terpencar lokasinya satu dari yang lainnya. Ini artinya juga bahwa inovasi lebih mudah terjadi di dalam sebuah klaster. Pengalaman dari UKM di sentra industri logam di Tegal (Jawa Tengah) membuktikan pentingnya peran dari MNCs dalam peralihan teknologi, di satu sisi, dan penyebaran dari teknologi tersebut antar sesama UKM di dalam sentra tersebut. Bahkan peran MNCs lebih besar daripada bantuan teknis dari pemerintah lewat penyediaan unit-unit pelayanan teknis (UPT).

\section{G. Simpulan}

Pemberlakuan MEA dapat membawa dampak positif dan negatif $\mathrm{t}$ e $\mathrm{r}$ hadap $\mathrm{U} M \mathrm{KM}$ yang ada. U $\mathrm{nt} \mathrm{u} \mathrm{k}$ m enghadapi d ampak negatif yang ada, perlu adanya starategi agar UMKM tetap dapat eksis dan terus berkembang. Salah satu strategi tersebut adalah pendekatan klaster. Pendekatan ini dilakukan dengan mengelompokkan industri inti yang saling berhubungan, baik industri pendukung (supporting industries), industri terkait (related industries), jasa penunjang, infrastruktur ekonomi, penelitian, pelatihan, pendidikan, infrastruktur informasi, infrastruktur teknologi, sumber 
daya alam, serta lembaga-lembaga-lembaga terkait. Klaster juga merupakan cara untuk mengatur beberapa aktivitas pengembangan ekonomi.

Strategi Meningkatkan Daya Saing Industri dalam Menghadapi Masyarakat Ekonomi ASEAN (MEA) ini dilakukan dengan:

1. Penggunaan kompetensi inti dalam mengupayakan untuk meningkatkan daya saing klaster.

2. Menciptakan kunggulan kompetitif yang dimiliki $\mathrm{k} 1$ a s $\mathrm{t}$ er yang didasarkan pada pendekatan RBV. 


\section{DAFTAR PUSTAKA}

Ana Syukriah dan Imam Hamdani, "Peningkatan Eksistensi UMKM Melalui Comparative Advantage dalam Rangka Menghadapi MEA 2015 Di Temanggung", dalam Jurnal Economics Development Analysis Journal, Edaj 2 (2) (2013)

Husni Mubarok, Manajemen Strategi, Idea, Yogyakarta, 2009.

I Wayan Dipta, Revitalisasi Koperasi Indonesia Menghadapi Era Globalisasi, INFOKOP Volume 20 - Juni 2012

Jaidan Jauhari, "Upaya Pengembangan Usaha Kecil Dan Menengah (UKM) Dengan Memanfaatkan E-Commerce", dalam Jurnal Sistem Informasi (JSI), Vol. 2, No. 1, April 2010.

Kacung Marijan, Mengembangkan Industri Kecil Menengah Melalui Pendekatan Klaster, dalam Jurnal INSAN Vol. 7 No. 3, Desember 2005.

Kementerian Koperasi dan UKM, Http://Depkop.Go.Id/Index. Diakses Tgl 18 Desember 2014 Pukul 12:30

Mudrajad Kuncoro, "Strategi Bagaimana Meraih Keunggulan Kompetitif", Erlangga, Jakarta, 2005.

Mudrajad Kuncoro, Irwan Adimaschandra Supomo, Analisis Formasi Keterkaitan, Pola Klaster dan Orientasi Pasar: Studi Kasus Sentra Industri Keramik Di Kasongan, Kabupaten Bantul, D.I.Yogyakarta, Jurnal Empirika Volume 16, No.1, Juni 2003.

Mudrajat Kuncoro, Masalah, Kebijakan, dan Politik Ekonomika Pembangunan, Erlangga,kota, 2010.

Neddy Rafinaldy, "Memeta Potensi Dan Karakteristik UMKM Bagi Penumbuhan Usaha Baru", dalam Jurnal Infokop Nomor 29 Tahun Xxii, 2006.

BISNIS, Vol. 3, No. 1, Juni 2015 
Pearce John A., Robinson Richard B., Formulation, Implementation, and Control of Competitive Strategy, McGraw Hill. 2009

Prihatin Lumbanraja, "Bersama UKM Membangun Ekonomi Rakyat Dan Lingkungan Hidup", dalam Jurnal Ekonomi Vol 14, No 2, April 2001.

Rusdin, Bisnis Internasional Dalam Pendekatan Praktik, jilid 1, Alfabetta, Bandung,2002

Sartono, Agus, Manajemen Keuangan Teori Dan Aplikasi $\left(4^{\text {th }}\right.$ ed), BPFE, Yogyakarta, 2010.

Sri Susilo,Strategi Meningkatkan Daya Saing UMKM dalam Implementasi CAFTA Dan MEA, dalam Jurnal Buletin Ekonomi Vol. 8, No. 2, Agustus 2010.

Suarja, W., Prospek Pengembangan Kredit Usaha Rakyat dalam Mendukung Pemberdayaan UMKM dan Koperasi, Harian Media Indonesia tanggal 23 November 2007, Jakarta

Tedjo Tripomo, Manajemen Strategi, Rekayasa Sains, Bandung, 2005, hlm. 106-107

Tulus T. H Tambunan, Industrialisasi di Negara Sedang Berkembang, Ghalia Indonesia, Jakarta, 2001.

Tulus T.H. Tambunan, UMKM Di Indonesia, Ghalia Indonesia, Bogor, 2009.

Widjajani, Gatot Yudoko, Industri Kecil Tradisional Dengan Pendekatan Berbasis Sumber Daya: Studi Kasus Pengusaha Industri Kecil Logam Kiara Condong, Bandung, dalam Jurnal Teknik Industri Vol. 10, No. 1, Juni 2008: 50-64.

Yuli Wibowo, et.al, Strategi Pengembangan Klaster Industri Rumput Laut Yang Berkelanjutan, dalam Jurnal Agritek Volume 12 Nomor 1 Maret 2011. 
